has twice as much consciousness as another?

There can also be too much gee-whiz science for my taste. For instance, talking about the nervous system of the worm Caenorhabditis elegans with its 302 neurons, Koch describes the creature's "state of consciousness" as the current position of the system on a 302-dimensional graph, with $2^{302}$ possible states (for each combination of the 302 neurons either firing or not). The neural network is a material thing, Koch argues, but the shape of the graph describes the conscious experience of the worm at that moment, "its phenomenal experience".

By this argument, the 32,768-byte computer file holding this review has a consciousness defined by its position on a 32,768-dimensional graph with $256^{32,768}$ (or, put more quaintly, 1 followed by 87,000 zeros) possible states. Personally, I don't think any of them have much chance of being conscious.

There are other points on which Consciousness lacks clarity. Koch tackles most of the big questions: are mice and fruitflies conscious (yes); can computers be conscious (yes); are they already (yes); is there free will (not really); can we ever understand consciousness (yes); can the mind affect our behaviour (no); and even is there a god (yes, but absent since the Big Bang).

$\begin{array}{ll}\text { "What does } & \text { Unfortunately, it } \\ \text { it mean to } & \text { is often hard to } \\ \text { say that } & \text { thesipher which of } \\ \text { one system } & \text { proven facts, which } \\ \text { has twice } & \text { personal beliefs and } \\ \text { asmuch } & \text { which momentary } \\ \text { consciousness } & \text { opinions. }\end{array}$

In fairness, the equations are much more complicated than is described here. Still, in the end, the theory seems to me to be an example of a conflation of ignorances: saying that because we don't really understand A or B, they must be causally related. Whether they invoke quantum mechanics, microtubules or integrated information content, these explanations speculation. Perhaps one of them is actuphilosophers searching for the cause of thunder, we are still thousands of years from an answer.

I argued with Koch all the way through this book. And I loved every minute of it.

Robert Stickgold is an associate

professor of psychiatry at Harvard

Medical School in Boston, Massachusetts. e-mail:rstickgold@hms.harvard.edu of consciousness are, for all their mathematical precision, no more than pure ally right. But perhaps, like ancient Greek

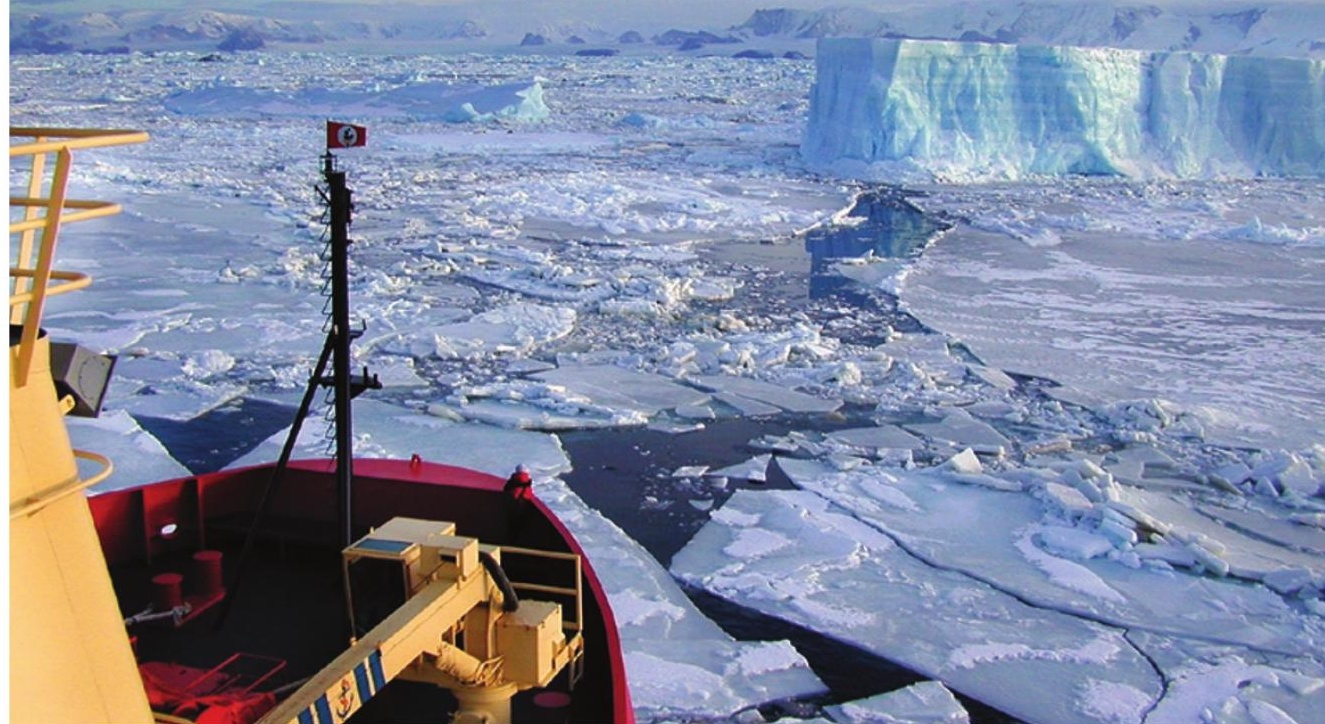

Humans have been probing the mysteries of the Antarctic for almost 200 years.

POLAR RESEARCH

\section{Deep-frozen science}

\section{Francis Halzen is exhilarated by a trek through stories of research and exploration in Antarctica.}

A dazzling array of narratives throngs Antarctica, collected from scientists in one of Earth's most extreme environments. Science writer and consultant Gabrielle Walker gathered these stories in the course of five trips criss-crossing the continent, mostly as a guest of the US National Science Foundation's Antarctic programme.

This is not just a highly accessible encyclopedia of Antarctic science. It interlaces researchers' stories with natural history, tales of the 'heroic age' of exploration and passages that viscerally describe the cold, isolation and beauty of the environment. Neatly organized geographically, the book covers the East Antarctic coast, with McMurdo Station (the largest community in Antarctica) and the penguins; the high plateau, with the Concordia and South Pole research stations; and the isolated West Antarctic coast.

Walker talks about the Dry Valleys near McMurdo, which run from the edge of the ice sheet that covers most of the continent down to the Ross Sea. Precious little precipitation has fallen here for millions of years: with an average temperature of $-55^{\circ} \mathrm{C}$, this is Mars on Earth. But it is teeming with life - cyanobacteria, found in ponds the world over. Here, they live inside the dry rock, surfacing for only a few weeks a year to find water from the little snow that fell over winter. Then they go back to sleep.

Walker learned that fascinating story on a diving expedition in Lake Hoare in the Dry Valleys with Peter

\section{To read about} Antarctic research 100 years ago: go.nature.com/9fbuuj

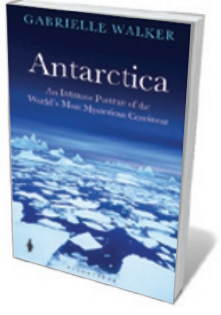

Antarctica: An Intimate Portrait of the World's Most Mysterious Continent GABRIELLE WALKER Bloomsbury: 2012. 416 pp. £20
Doran, a biologist at the University of Illinois at Chicago. But it isn't only researchers who feature here. The book is peppered with characters who "keep the scientists alive". On one trip we meet camp manager Rae Spain, who came to Antarctica as a carpenter and returned because she could not get the continent out of her head. "It haunts you," she told Walker.

Mars has literally come to Earth just beyond the Dry Valleys, Walker tells us. Researchers on Skidoos systematically scan the ice sheet for meteorites - a relatively easy task, given that everything stands out in this icy landscape. We accompany John Schutt, a mountaineer who has returned for the hunt every year since 1980 . More meteorites have been found since the 1970s in Antarctica than over centuries in the rest of the world.

In 1982, for the first time, an Antarctic meteorite was identified as coming from the Moon. Two years later, researchers found a rock from Mars that turned out to contain structures that may be nanoscale fossils: the most intriguing indications yet that life may have existed on other planets in the Solar System, although debate is still raging.

The West Antarctic coast, as Walker shows, is out of reach of the permanent 
scientific stations, and difficult to approach by vessel. This is where gigantic glaciers empty into the Pacific Ocean, and studies have revealed rapid changes in the ice flow. Helen Fricker, a glaciologist at the Scripps Institution of Oceanography in La Jolla, California, has traced these changes to subglacial lakes linked by canals, which form a dynamic hydrologic system on which the ice slides to the sea. Walker journeys across the inhospitable glaciers, where she stands on ice flows the size of Niagara Falls with George Denton of the University of Maine in Orono, a veteran in 'reading' glacial landscapes.

Some of the historical vignettes will be familiar, such as the race to the South Pole between Norwegian explorer Roald Amundsen and his trained team, and Robert Scott, British hero of scientists, who presumably found Amundsen's efficient approach ungentlemanly. Other stories are less well known, such as that of Australian geologist Douglas Mawson, who travelled to the south magnetic pole as part of Ernest Shackleton's Nimrod expedition and later led a disastrous research trip to Adelie Land, on which two men died.

Tales of those expeditions, and the scientific ones that followed, remind us that people have been travelling to Antarctica for almost two centuries, ever since seal hunter Captain John Davis first set foot there in 1821. The Antarctic Treaty, signed by 49 countries, has since 1961 guaranteed that the continent is reserved for science. High technology has now arrived: the collaborations behind the South Pole Telescope and the IceCube Neutrino Observatory have constructed the kinds of instrument that are more routinely built at laboratories such as Fermilab near Batavia, Illinois, or CERN near Geneva, Switzerland. IceCube collects a few hundred neutrinos per day, some with energies that exceed those at earthbound accelerators by more than two orders of magnitude.

Yet Antarctica is still the "world's most mysterious continent", as it remains the only one on which humans have never lived permanently. Walker captures that mystique through interviews with people who have made Antarctica part of their lives. Perhaps the most notable among them are the "telescope nannies", who return each year in early February to spend the long Antarctic winters at the South Pole, taking care of the scientific equipment and data acquisition after scientists have boarded the last planes back to their universities. Their arduous job brings a rare reward: a sense of the untrammelled isolation of this vast continent.

Francis Halzen is the principal investigator of the IceCube project, and Hilldale and Gregory Breit Professor in the department of physics at the University of WisconsinMadison.

e-mail:halzen@icecube.wisc.edu

\section{Books in brief}

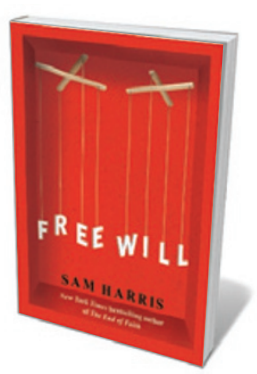

\section{Free Will}

Sam Harris FREE PRESS 96 pp. \$9.99 (2012)

Neuroscientist Sam Harris, the author of the bestselling The Moral Landscape (2010), here skewers the concept of free will — that mainstay of law, policy and politics — in fewer than 100 pages. Using evidence drawn from psychology and neuroscience, Harris asserts that the course of human life is all down to luck, and that willpower is a "biological phenomenon". We are not in charge of our own minds, he says: thought and intention simply arise. This is a tract that is sure to boldly go straight to the heart of the determinism debate.

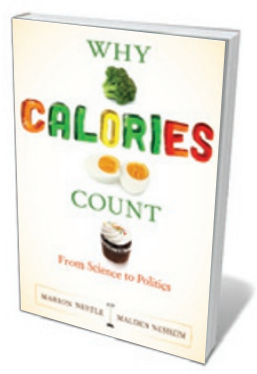

Why Calories Count: From Science to Politics

Marion Nestle and Malden Nesheim UNIVERSITY OF CALIFORNIA PRESS 304 pp. $\$ 19.95$ (2012)

Obesity has gone global — as has misinformation about nutrition and food. Nutrition scientists Marion Nestle and Malden Nesheim unscramble the confusion with a serving of science. They reveal how calories - those potent but ill-understood measures of heat energy - are really counted, why we need them, how we use them, how many we actually need and why it all sometimes goes so wrong. From 'secret' calories to food politics, malnourishment and calorie restriction for health, this is a feast for the mind.

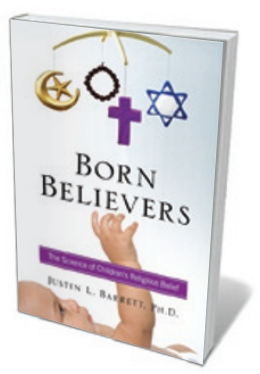

\section{Born Believers: The Science of Children's Religious Belief} Justin L. Barrett FREE PRESS 320 pp. $\$ 26.00$ (2012)

Psychologist Justin Barrett says that belief is rooted not in indoctrination, but in a default setting of the infant brain. A range of findings in developmental psychology, he argues, support the theory: very young children, for instance, are aware that nature is not designed by humans; and people tend to look for unseen agents behind natural phenomena. Barrett says that the evidence points to a universal "natural religion" - but he also argues that parents must not impose belief systems on their children, and should leave the question of whether to die a believer up to their offspring.

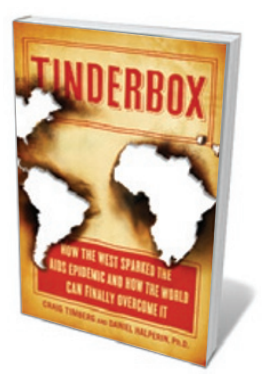

Tinderbox: How the West Sparked the AIDS Epidemic and How the World Can Finally Overcome It

Daniel Halperin and Craig Timberg PENGUIN 432 pp. \$29.95 (2012)

The butchering of a chimpanzee in Cameroon about a century ago may have been when simian immunodeficiency virus crossed into humans and became HIV. But, argue epidemiologist Daniel Halperin and journalist Craig Timberg, European greed and technologies sparked the HIV pandemic. Trade routes, the growth of colonial cities, a decrease in male circumcision and a rise in prostitution effectively incubated and spread the disease - and Western programmes to curb it in Africa have proved mostly ineffectual, say the authors.

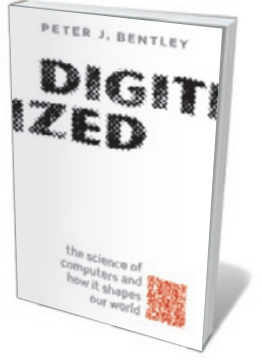

Digitized: The Science of Computers and How it Shapes Our World Peter J. Bentley OXFORD UNIVERSITY PRESS 256 pp. £16.99 (2012) The wiring of the world - from a glint in Alan Turing's eye to global domination - is neatly encapsulated by computer scientist Peter Bentley. An enthusiastic guide, he lays this compelling history bare, explaining the science as he goes: Moore's law of processing-power growth, the circuit designs of Claude Shannon, John von Neumann's early electronic digital computer, neural networks and the staggering array of applications for computing in everything from pizza delivery to Alzheimer's-disease research. 